\title{
How Effective is the U.S. National Security Strategy Policy in Protecting the American People?
}

\author{
Dr. Phillip D. Clingan
}

\begin{abstract}
This study discusses the National Security Strategy (NSS) Policy and policy enforcement practices at the Executive Branch level. The research examines and compares the negative and positive impacts of the Executive Branch and the execution of the NSS Policy. A literature review addressing the issue was conducted on primary and secondary sources, which were retrieved from government archives and other sources of data such as institution libraries. The main question behind the study was how practical the United States NSS Policy is in protecting the American people. According to the literature review, NSS policy is a critical element in protecting U.S. citizens. It offers a platform for the leading elites to explain the security priorities of the country. Despite being criticized as verbose and lacking specific actionable objectives, the NSS has benefitted U.S. citizens. The policy has been cited as reducing terrorist activities in the world and increasing the safety of American citizens. The policy has offered bases for various actions taken by the American government to protect its citizens, not only on American soil but also in other parts of the globe. Most national security policies illustrate how policies are in a constant state of change and transition as evidenced by changes in international policies between the Obama administration and the previous regime of President Bush. There is a future need to conduct further research on the overall impacts of some policies adopted by the state because they have been faulted as causing more insecurity to the American people.
\end{abstract}

Index Terms-National Security Strategy

\section{INTRODUCTION}

"No national security strategy is complete in the long run without promoting global health, political freedom and economic progress."

George W. Bush (2010)

For over a decade many citizens of the United States have questioned the politicization of the intelligence surveillance collection process, the increase of clandestine operations, and the treatment of those suspected of terrorism against the United States. Most agree this issue demands attention, as policy enforcement from the Executive and Congressional branches has established policy based on perceptions of the environment. This policy may weaken the values of the United States.

This literature research examines several opinions about National Security Strategy (NSS) Policy and policy enforcement practices at the Executive Branch level. The research analyzes and compares the negative and positive impacts of the Executive Branch and the execution of the

Dr. Phillip D. Clingan, Criminal Justice \& Social Sciences, Pierce College/ Lakewood WA., United States
NSS Policy. It addresses the following research question and hypotheses:

1. How effective is the U.S. National Security Strategy Policy in protecting the American people?

Ha. The U.S. National Security Strategy Policy is effective in protecting the American people.

H0. The U.S. National Security Strategy Policy is not effective in protecting the American people.

This review illustrates how effective the U.S. NSS Policy is in protecting the American people. The policy identifies the need for a comprehensive solution and demonstrates the approach of the Executive Branch to this complex problem.

The executive branch of the government periodically prepares the NSS document of the United States for Congress. It includes input from multiple federal-level agencies and defines specific outcomes that must be achieved [8]. The NSS also outlines the major national security concerns of the United States and how the administration plans to deal with them. Since 1986, the Goldwater-Nichols Department of Defense Reorganization Act has required the President to submit an annual NSS Report [22]. The National Security Council, managed by the national security advisor and employing its committee system and the interagency process, develops the NSS under section 404a of Title 50, United States Code [1].

Integrating all the elements within the NSS involves an opaque and irregular set of rolling negotiations among national security principals [10]. The 2002 NSS, issued in the immediate aftermath of 9/11, stipulated that the United States is at war with transnational terrorism fueled by a perversion of Islam and proposes stable democracy as the primary solution, supported by aggressive efforts to control the proliferation of weapons of mass destruction and the option of taking preemptive military action. The 2010 NSS, in comparison, specified that the United States continues to stay in these moments of transition and has been at war with a far-reaching network of violence and hatred. President Obama claims in his 2010 NSS overview that "Just as America helped to determine the 20th century, we must now build the sources of American strength and influence, and shape an international order capable of overcoming the challenges of the 21st century" [15]. More important, the criteria for assessing national security strategies can be process-oriented or results-based.

The NSS should inform every citizen and government official of national priorities, policy positions, and decisions to be made during the next four years. The 2010 NSS expresses how warfare has changed and how the U.S. government must build a stronger foundation of leadership that can strengthen U.S. borders and influences beyond those borders. The 2012 NSS is future-based in 
matters that highlight President Obama's success in the fight against global terrorism.

A recent White House press release on foreign policy lays out a strategic approach for advancing American interests, including the security of the American people [15]. The reality of the NSS evolution demonstrates the need for a new paradigm of conflict because information-not firepower-is the currency upon which war is now conducted [14]. To support the values of the United States and implement the NSS directives to address the 21st-century challenges, the government must employ instruments of power. These instruments include intelligence, public diplomacy (both in the United States and abroad), and the security of the American people. The way these instruments are used must respect universal values at home and around the world.

Most important is the understanding of the big picture painted by the research, namely that to provide better security for the American people, the U.S. government must be prepared to confront and defeat aggression anywhere in the world [15]. By working with like-minded nations, the United States has created a more stable environment for the American people, our allies, and our partners around the world. The assessment of the NSS helps to develop other national security interests and to develop a defense strategy that not only prepares the United States for future challenges but also protects the United States effectively.

The NSS of 2010 identifies the strategic direction on which the U.S. government must focus on renewing American leadership to advance American interests in the 21st century. Though the NSS provides a broad and overarching strategic concept for ensuring the American people's security, the 2010 NSS lays out what the United States is about but does not clarify the priorities, or what resources are to be used to secure the American people better.

Political speeches, much like the 2013 State of the Union, which addresses the President's economic plan to strengthen the middle class and emphasizes investments in manufacturing, clean energy, infrastructure, and education while also addressing the federal deficit, do not clarify how to accomplish these tasks to serve or secure the American people more effectively [18]. There is a common theme easily recognizable where the President uses political speeches to address the people, arguing how new strategic and economic strategies are constructed to meet the American people's interests into the 21 st century better without connecting the two speeches or clarifying how to accomplish the speeches' topics.

The NSS of 2010 expands on the abilities of the American government to lead where economic power and opportunity are diffuse. President Obama, through repetition of statements, elaborates how committed he is to ensure the United States becomes a more resilient nation while using every government security agency at the local, state, and federal level to protect and secure the American people.

Finally, the NSS is an architecture of strategic design, one that builds a stronger foundation of U.S. borders and supports its allies and friends in ways that make the United States a nation proud to promote its values. The Executive Branch faces the challenge to bring all federal government departments together to deal with the nation's security issues.

\section{1) Purpose Statement}

This study project is to explore how effective the United States NSS Policy is in protecting the American people. The data compiled and analyzed describe the use of military mechanisms and national strategies facilitated by the President of the United States to further the functions of national security. This is regarding the national strategic policies approach as issued by the President, which is "the security of the American citizens and interests," [16].

\section{LITERATURE REVIEW}

For the past twelve years, the United States has continued to be at war with an enemy whose philosophy is violence and hatred towards the United States. The United States faces enemies from other nations, failed states, and non-state actors who look and seek opportunities to challenge its national security. The United States must maintain an unwavering commitment to the security of its citizenry, its allies, and its partners.

The strategy policy built around its national security must focus on and recognize the influences and strengths of the people within the United States. The U.S. government must take all steps necessary not just to capitalize on economic deficits or better education of its children, but to outline the steps the Executive Branch is taking to safeguard each citizen and strengthen U.S. alliances.

To reach a possible conclusion to the research question, several questions must first be answered. The first question is, "what responsibility does the President have regarding U.S. national security?" Second is the question, "how much authority does the Executive Branch have regarding national security?" The third is the question, "have the last two Presidents made any progress towards improving national security?" Last, "must the United States depend on its allies and partners for its national security?" Addressing these questions is essential before inquiring whether there is compelling evidence to determine how effective the United States NSS Policy is in protecting the American people. These questions of inquiry form the structure for this review of the literature.

The scope of this review is limited. Most national security policies illustrate how policies are in a constant state of change and transition. The majority of policies and primary and secondary materials reviewed are out of date by two or more years but bear directly upon the research question about the security of the American people through the NSS policy. More important; however, the research community needs more research.

\section{A. The U.S. President's Responsibility Regarding National Security}

President Obama signed his NSS Policy in May of 2010 and updated the policy known as "Sustaining U.S. Global Leadership: Priorities for 21st Century Defense" in January 2012. This clearly articulates the United States' approach to a broad and complex array of challenges to national security [16], which is the main point of the policy. The policy further illustrates the determination to build upon and shape an international order capable of overcoming the future challenges of the 21 st century. The word "order" refers to maintaining systemic order in international relationship 
building. This section exemplifies the architecture of the policy plan while illustrating the global challenges taken on by the United States, its allies, and its partners.

The policy raises many positive and negative questions and doubts regarding the Executive Branch's use of power and the real intent of the policy. The NSS Policy is facilitated through the Executive Branch. The negative aspect of the NSS Policy is the possibility that the "President is free to act as necessary, even if in violation of statutes, treaties, and the Constitution," to support the policy [21].

A common theme seems to repeat itself between the NSS Policy of May of 2010 and the updated policy of January 2012. This common theme is how these policies read more like the State of the Union address and raise the question of what the United States is about in such broad strategic terms that most Americans might question where the value is. President Obama starts his new national security policy by stating "This is a review" and then describes how the American people shape the policy [18]. The President continues to claim his responsibilities repeatedly throughout each policy by asserting that he safeguards the American people and their interests [18].

More important, the NSS Policy is broad and verbose and does not express in common language terms a step-by-step action needed to illustrate fully how these actions stem from a policy rather than from abroad strategy being called a policy. The President uses "we" in a context throughout the security policy that frames a natural understanding of his intent and overall concept; that as a nation we must build and strengthen ourselves [16] Regarding this example of broad wording and generalization of policy language, the President relied heavily upon his national security speechwriter.

In this regard the policy design does not clearly define the President's responsibilities regarding achieving national security; it fails to describe these responsibilities or to provide any strategic leadership. Therefore, the 2010 NSS Policy supports the null hypothesis because the policy does not explain how strategy is prioritized or how national security is to be resourced and nor does it clearly define which mission sets or national objectives are more important than others.

\section{B. The Executive Branch's Authority Regarding National Security}

The NSS Policy intends to represent areas of particular priority, such as security, prosperity, values, and international order [16]. These areas are critical to securing the United States in the 21 st century. This policy details explicitly the security of the United States, its citizens, and U.S. allies and partners as a strategic approach.

The Obama Doctrine, by Dave Rohde, claims that President Obama has transformed himself from the former constitutional law professor promising American citizenry new fuel technologies to embrace the word of "terror," enabling the Executive Branch to expand its powers to facilitate clandestine war better [20]. The scope of this research is highly relevant to the research question and expands upon the actual effectiveness of the Executive Branch. The Executive Branch also appears to be in pursuit of destroying all terrorist threats to the United States and its allies through means of counterterrorism-sanctioned kills. This is the main point of the article.
The most solemn responsibility of the President and the U.S. Government is to protect the American people, both at home and abroad [17]. Rohde illustrates how the Executive Branch is not upholding the rule of law by facilitating clandestine war, but herein lies the disconnect between Obama and Rohde. The national strategy for counterterrorism exemplifies the Executive Branch's commitment to maintaining a durable legal framework for counterterrorism operations and bringing terrorists to justice [17]. There is some conflict between Rohde's view of the Executive Branch and the President's perception of counterterrorism policy, which is the key to understanding if and how the Executive Branch applies its counterterrorism capabilities appropriately.

The counterterrorism policy supports Rohde's argument because the counterterrorism policy is written so broadly using pro-policy words like "pursuing efforts" and "balancing near-and-long term considerations" [17]. With such wording in a policy that should be written more clearly so every American citizen can understand how the government is protecting the people, not surprisingly, the Executive Branch is overreaching its authority and goals to protect the citizenry.

Jules Lobel and F. Turner Robert, authors of "Covert War and the Constitution," claim that modern Presidents have argued that the Executive Branch has the power to authorize the use of covert paramilitary force without approving Congress and have done so successfully [13]. Congress has been known historically to limit or end funding for particular covert paramilitary operations but has not required the Executive to obtain congressional approval beforehand. Despite the Executive Branch's ability to wage clandestine war, the evidence supports Lobel and Turner's argument that covert paramilitary actions must under the Constitution be debated and approved by Congress.

Rohde (2012) and Lobel and Turner (2012) argue whether the President has the constitutional power to authorize covert paramilitary actions and that the Executive Branch continues to wage clandestine war without Congressional approval and has historically since 1806. Despite the issued statements by the President that his actions should safeguard the American people and their interests, these authors continue to debate the constitutionality of the covert war by the Executive Branch. Lobel claims this specific issue of the Executive Branch authorizing covert paramilitary actions or shadow wars against other nations or entities has existed since the early American republic and continued to vex policymakers today [13]. This issue needs more research.

During President Obama's 2010 NSS speech, Obama asserted that he bears no greater responsibility than ensuring the safety and security of the American people [9]. A year later, when addressing the Homeland Security Director, the President stated once more, "I carry with me every moment of every day-the responsibility to protect the safety and security of the American people." The President continues to illustrate that the United States is at war against a far-reaching network of violence and hatred. He further asserts that the Executive Branch will do whatever it takes to defeat terrorism and defend the United States. This article reinforces the issued statements by the President on his activities to secure the citizenry. 


\section{Have the Last Two Presidents Made Any Progress Towards Improving National Security}

Another general criticism regarding national security is expressed by Michael Desch, who claims "that as the more things change, the more they stay the same: [this is] the liberal tradition of Obama counterterrorism strategic policy." Desch raises an interesting point about the security of the American people and questions if the counterterrorism policy is keeping the American people safe [7]. Desch continues to assert that the United States is still at war, with the war that started under G.W. Bush continuing under the Obama administration. He questions the weight of the policy's impact on ending the war and keeping the American people safe. The argument in Desch's claim illustrates the lack of clarity in both presidents' attempts to suggest how the counterterrorism policy outweighs the arguments to justify war while undermining the civil liberties of the American people.

The article supports the null hypothesis by asserting that Obama's only intent is to use the "counterterrorism policy as a political cover that is widely regarded as having failed in making America safer after September 11" [7]. Another security policy may not be needed as the Executive Branch is using the U.S. Counterterrorism Policy as the primary means to give direct support to the U.S. NSS Policy.

The President's speeches support the null hypothesis, but the United States is tired and wearing down due to the recent recession. The American people are safer today than 12 years ago, as asserted by President Obama in his opening comments on national security policy [16]. The United States has become more united because "we the people" understand the gravity of determination and what is essential to safeguard the United States. The speeches only address the positive impact of preserving the people; they do not mention the other factors that directly impact the nation at the lowest level, the people. The speeches only address what has happened, not how the people can move forward after today.

President George W. Bush issued and addressed the nation in June 2002 with a new policy titled "The National Security Strategy of the United States of America." Not once in his opening remarks of three pages does he state that the policy intends to protect and or secure the people of the United States [3]. President Bush claims the policy to defend the nation against its enemies is the first and Constitutional responsibility of the federal government [3]. President Barack Obama issued and addressed the nation in May 2010 with a modification of that policy, titled "National Security Strategy" and in his second paragraph, he states "we will be unwavering in our commitment of the security of our people, allies, and partners" [16]. Two Presidents speak openly and proudly of their attempts to safeguard the United States and its government, but only President Obama continues to issue claims about the security of the people.

More important, any layperson reading these three articles from Presidents Bush and Obama and by Michael Desch may have the opinion that a dark cloud has descended upon them, the nation, and possibly its allies, who may conclude that the United States plans to dominate the world. All three articles express a campaign to seek and destroy all enemies that threaten the United States, its allies, and its partners, but only President Obama aims to use the NSS policy to secure the American people and its interests addressing the research question. This issue also needs more research.

\section{Must the United States Depend on Its Allies and Partners for Its National Security}

President Obama asserts that the United States must continue to strengthen and influence global leaders and this relationship-building will make America stronger and more secure, so it will be more able to overcome challenges [16]. Unfortunately, the grand strategy of the NSS policy emerged from trials and tribulations of recent American history. What the policy provides is a verbose guarantee of security to the American people and government into the 21 st century.The above policies collectively declare the importance of identifying weaker global states and the importance of providing leadership to the international community. When weaker nations fail to police themselves, they become a target for terrorism; the international community must come collectively to face the challenges of the global system [12]. The Defense Secretary makes a bold and bright statement to the research question, "The United States must strengthen and expand alliances and partnerships" [12]. The Secretary of Defense illustrates the importance of a strong defense without actually explaining how international order applies to the interests of the United States. The policy speaks of global alliances that support its values and economic prosperity but does not tell how the policy applies directly to national security.

Both Obama and Gates advocate strongly for a successful administration to provide an overarching strategic concept for ensuring the nation's security, but broad terminology does not establish or identify which steps are more critical than others to achieve the administration's intent. Doyle argues against the wording of the NSS policy because the policy does not clearly define a step-by-step strategy for implementation [10]. More critical, Doyle further claims that "worldwide interest, goals, and objectives of the U.S. are vital to the security of the U.S." [10]. The broad language is necessary to illustrate the overall capabilities and conceptual details of implementing foreign policies and national security strategies.

The White House's view of Foreign Policy may clarify the need to rely on allies and partners to accomplish national security policies and keep the American people safe. The White House Foreign Policy release of November 2012 illustrates clearly the progress of foreign policy directly linking to the security strategies of the U.S. government.

For example, since taking office, President Obama has conducted global summits to address security challenges, eliminated Osama bin Laden, presented a National Strategy for Counterterrorism, implemented a new strategy for Pakistan and Afghanistan that seeks to dismantle and defeat al Qaeda, led an international coalition to stop a massacre in Libya, and presented and promoted democratic reform, economic development, and peace and security across the Middle East and North Africa [15]. There are many more accomplishments to be noted, but more important is the unprecedented and unequaled strength and influence the United States now has on the world. Further research is also needed on this issue. 


\section{THEORETICAL FRAMEWORK AND METHODOLOGY}

\section{A. Description}

The research evaluation was carried out by using a qualitative approach to collect from secondary resources like peer-reviewed journals, primary sources, and the writings of several authors including President Barack Obama and Richard B. Doyle. Using the qualitative approach has proven to be very useful in formulating and analyzing a comprehensive evaluation of the research question. Additional data about the U.S. NSS Policy came from a collection and discourse analysis of data to support the qualitative inquiry.

\section{B. Research Methodology}

The methodology for conducting this research was a collection and discourse analysis and an interpretation of secondary and primary sources to support a qualitative inquiry. Data were collected via multiple NSS Policy and Sustaining U.S. Global Leadership: Priorities for 21st Century Defense reviews, which were conducted while evaluating the Executive Branch's ability to protect the American people effectively.

\section{Research Plan}

The research plan is to determine the strength and weaknesses of the U.S. NSS Policy to determine if the policy supports the null hypothesis or the alternative hypothesis. The U.S. President is the principal director of the formulation of the U.S. NSS Policy that ensures the safety and security of the American people. The policy is a guide set out by the intelligence communities, homeland security personnel, the U.S. military, and policymakers, ensuring they all meet the intent of the Executive Branch. The executors of the policy have to reach the comprehensive range of national actions and an all-encompassing concept of what constitutes national security. The Obama Administration has committed to active consultation with Congress and receives robust and effective oversight of its national security policies to support the U.S. NSS Policy better.

\section{Design Statement}

This research used a qualitative approach by collecting primary and secondary sources as evidence to answer the research question. This strategy illustrated differences between authored claims and assertions within the literature review to clarify if the gaps of information support the alternative hypothesis or the null hypothesis.

The validity of the results greatly depends upon the quality of resources available and the researcher's judgment on whether the data supports either the null or alternative hypothesis. The qualitative approach is a generalized method. A systematic analysis of the literature was carried out, applying a rigorous focus to the research questions.

\section{FINDINGS AND ANALYSIS}

A qualitative analysis was conducted on the primary and secondary sources that addressed the central questions of the study. The review targeted documents and articles that covered areas relating to the effectiveness of NSS policy in protecting U.S. citizens. The analysis was conducted referring to the first four years of the Obama administration. The findings of the literature review partially follow the null hypothesis of the study. The analysis reveals a two-sided argument between the administrators, who dispute the null hypothesis, and scholars, whose work supports the null hypothesis. The review assessed the responsibility of the President regarding national security, the authority of the Executive on security issues, the progress made by the last two Presidents toward improving national security, and the U.S. dependence on allies and partners in national security.

The null hypothesis of the study was that "The U.S. National Security Strategy Policy is not effective in protecting the American people." The discoveries of this study are organized according to the central questions highlighted at the beginning of the literature review. The United States remains a powerhouse regarding economy, the Military, and democratic leadership. Most countries in the world look up at the United States as an example of good governance. It is, therefore, expected that the policies of the United States in all areas should be specific, comprehensive, and to the point of the issue, they are addressing. The study reveals that despite the role assigned by the constitution to the president, the current and previous presidents have failed to develop a precise NSS that is specific and that addresses the current needs of American security.

\section{A. The Responsibilities of the President Regarding National Security}

The executive arm of government is assigned the responsibility of facilitating national security policy. The president represents the arm. The Congress requires the President to outline and submit NSS reports to the Congress annually. This strategy describes the specific security outcomes that have to be achieved by the government of the United States. The administrative arm of the government is assigned the responsibilities of being the leading foreign affairs policymaker [23]. This is achieved through the executive role of the President and the powers and mandates of the Department of State.

The President of the United States adopted a broad NSS that seeks to respond to the dynamic security needs of the country and the world. In his reviewed strategy [18], the President outlines the central theme of the strategy as creating a world order that has the potential to respond to the challenges of the 21 st century. This is a broad approach to national security, despite the stated role of maintaining security and order in the world. This policy also raises questions on the executive powers of the President to "act as necessary." This has been the point of conflict between the role of the President in executing his powers and his duties of defending U.S. citizens.

The policy adopted by the President is a description of where the country is in broad terms. It fails to underpin the values of the policy. The policy outlines the responsibility of the president to protect and safeguard Americans. The policy is not specific. Broad statements that lack measurable 
outcomes characterize it. It is not detailed on a course of actions necessary to accomplish what it has set. The constant use of the word "we" should give the policy the state touch. However, the same world portrays the policy as broad and unspecific. The policy is highly generalized, and it is characteristic of a political statement rather than an actionable policy document.

The policy is also inadequate in defining the role and responsibilities of the president in the realization of national security. It does not meet its intent of offering strategic leadership on which decisions and actions are to be based. The characteristics of this policy adopted by President Obama lack actionable objectives. It does not highlight the objectives of the country regarding security and neither does it identify prioritization of issues.

It can, therefore, be concluded that most national security policies as developed by the Executive arm of the government (in this case the President) are merely political statements that lack specific objectives but dwell much on asserting the position of United States in the world. Under the constitution of the United States, protecting the nation is the essential role of the President. The two Presidents reviewed seem to agree with these constitutional requirements. Despite their broad approach to national security, NSS Policies adopted by the two most recent Presidents have contributed to keeping the nation safe.

\section{B. The Role of the Executive (President) Regarding National Security}

Terrorism is one of the security challenges that have attracted international attention and the efforts of the U.S. government. The $9 / 11$ attacks are a vital policy-changer regarding foreign policies and protection of United States citizens, both at home and abroad. The incident also re-invigorated the long-standing debates on the authority of the Executive Branch toward national security. The President is mandated with developing the NSS Policy. The policy serves as the basis of prioritizing actions and decisions. The policy is expected to detail the security of American citizens, allies, and partners across the world. The effectiveness of the NSS Policy in protecting American citizens can be assessed concerning initiatives instituted based on the policy's ability to actualize its mandate of protecting the citizenry.

According to Louis Fisher [11], over the years, American Presidents have adversely used their national security powers to the detriment of their political parties, the nation, themselves, and different parts of the world. The effective deployment of military force and foreign policy plans requires consensus-building, public participation, and compliance with state laws. Several Presidents have used uninformed references to the clause on the Commander-in-Chief to commit the country to war. This illustrates a single claim to power.

The United States has received critiques from different quarters for its foreign policies; cases at hand include the U.S. support of Guantanamo Bay and dentition without trial. The President and the government should demonstrate respect for the Constitution and decisions should be made in consultation with Congress to create federal support for policies that the government adopts. It is through such a consultative and constitutional process that other countries can understand that decisions taken by the U.S.
President have broad support and are not unilateral actions taken by the President.

More often Presidents of United States have failed to respect the Constitution in times of emergency. This trend has become common any time the country faces crises emanating from international terrorism or threats to the country's strategic interests overseas. However, the legitimization of such actions is unfounded because the state has a legal framework to address the national security issues. This argument coincides with the position held by Lobel and Turner (2012) that questions government involvement in clandestine wars. One such example where the United States adopted such a policy was in response to 9/11 terror attacks. Despite these criticisms and questions over the effectiveness of war against terrorism, the current administration has reduced terrorist activity.

The Executive Branch has invested a lot of resources in combating terrorism all over the world. Threats of terrorism remain rife, and the government has to stay firm in protecting U.S. citizens. However, questions have to be raised over some wars in which the country has engaged in the name of countering terrorism. The war on Iraq and the recent intervention in Libya that led to the ouster of President Gaddafi are some wars in which the country has engaged that remain controversial.

As demonstrated by President Obama's 2010 speech on NSS, the executive (President) accepts that the responsibility of protecting U.S. citizens lies squarely on his shoulders. The President reaffirmed his commitment to ensuring the security of all citizens. It is the Constitutional and moral duty of the Executive to protect all citizens and provide security to citizens in the United States and beyond. The strategy adopted by each President differs. The Obama administration has been operating on some policies that were approved by the Bush administration. However, specific changes of practices have been witnessed during Obama's first four years of the administration.

\section{Comparison of Security Strategies between Bush and Obama Administrations}

The Counterterrorism Policy appears to be the leading policy upon which security decisions and actions have been based since the $9 / 11$ attacks. However, queries have been raised on the efficacy of this policy in assuring the citizenry of their safety [7]. The continuation of the Counterterrorism Policy by the Obama Administration has raised questions on the responsiveness of the NSS to the will of the people. The focus of the counterterrorism policy is to fight the enemies of the United States all over the world and to offer support to its allies.

This approach may be creating more enemies rather than ensuring the safety of U.S. citizens. However, the country has successfully avoided a major terrorist attack since the 9/11 attacks. The President is optimistic that U.S. citizens are safer now than 12 years ago. This has been achieved by applying Counterterrorism Policy. Using this policy to guide the NSS requires a focused analysis. The government should show the way forward by investing a lot of resources on combating terrorism and addressing the changing security needs of the country. The nation is in a continuous state of war with the perceived enemies of the people. These constant "wars" may hurt the security of U.S 
citizens and are expensive: the Iraq war cost the United States billions of dollars and thousands of American lives.

One of the common characteristics of NSS adopted by both President Obama and his predecessor is a commitment to protect and secure U.S. citizens. Bush outlined that the original intent of NSS was to defend the nation against its enemies. This policy fails to encompass the concept of the people. Its focus is on the enemy and not the U.S. citizenry. President Obama uses a modification of the same policy. The policy adopted by President Obama refers to the security of the people. This reference to the people indicates a commitment to national security to protecting the citizenry.

However, the policy changes with the holder of the Presidential office. This leaves the policy open to manipulation by political leaders to fit their agendas. NSS is a critical component of ensuring the safety of the citizens. It offers the administration a channel to develop its strategic action to secure the people of America. The NSS Policy is critical in providing legal and financial support to the security endeavors of each government. However, the policy is prone to manipulation and misuse by those in leadership positions. This is demonstrated by the difference between how President Bush used the policy to attack Iraq and how the same policy was used to attack al-Qaeda hideouts in Afghanistan [2]. A non-political NSS would be more efficient in ensuring the security of American citizens. There is a considerable volume of data and information on national security, which requires in-depth analysis to conclude on its effectiveness.

\section{The Role of U.S. Allies and International Alliances in National Security}

World peace is an international endeavor. That the United States has to depend to some extent on partners and allies for national security should be addressed in the multidimensional and global nature of the modern threat to security. Former and present leaders of the United States have continued to insist on strengthening relationships with other friendly nations and offering global leadership. The NSS policy adopted by the President fails to address failed states, which are prone to terrorism and act as good incubation sites for terrorism. When dealing with international alliances, the NSS offers no clear relationship between the international order and the security of the United States. It provides no step-by-step course of action that guarantees the safety of the country [10]. However, the continued efforts of the United States to restore stability in some territories of the world have been associated with improvements in national security.

A case in hand is the United States' military intervention in Afghanistan and Pakistan, which resulted in the weakening of al Qaeda, which was one of the largest and most dreaded terrorist groups. The effort of United States culminated in the capture and death of Al Qaeda leader Osama bin Laden. The nation has also played a crucial role in promoting peace deals in the Middle East. However, the overall impact of the United States' intervention in the international field on national security remains a tricky balance. The country's position in the Middle East to support Israel has created some dissatisfaction among some Muslim countries such as Iran. This has raised the questions of whether the United States' intervention in the Middle East is a benefit to the security of its people or is aggravating the already existing conflict.

\section{DISCUSSION}

NSS Policy is a critical element in protecting U.S. citizens. It offers a platform on which the leading elites indicate the security priorities of the country. The strategy is not entirely developed by the President, but it also incorporates ideas from the Department of State. The Constitutional intent of the policy is clear. However, the policy effectiveness in protecting U.S citizens is a subject of intense debate and analysis. The analysis of the above literature has revealed many areas of discussion and future insight. Despite its criticism as being verbose and lacking specific actionable objectives, the NSS has benefitted U.S. citizens.

The achievement of the policy has been cited as the reduced terrorist activities in the world and the increased safety of the American people. There is a need to conduct further research on the overall impacts of some of the policies adopted by the state. One such area is the overall impact of counterterrorism policy and the strengthening of international partnerships and alliances. The government should refocus on its NSS to address some issues that have been raised by critics. NSS Policies should strive to incorporate specific outcomes and be consistent instead of changing with each political leadership.

The capacity of this review is limited. Most national security policies illustrate how policies are in a constant state of change and transition. The majority of policies, primary sources, and secondary materials reviewed are out of date by two or more years but bear directly upon the research question about the security of the American people through NSS Policy. More important, though, the research community needs more research on this subject.

\section{CONCLUSION AND NEEDS FOR ADDITIONAL RESEARCH}

The research paper has explained the central importance of how the United States NSS Policy keeps the American people safe and secures U.S. interests. The research has argued that the security policy may not be the best instrument available to the Executive Branch for keeping the American people secure. Evaluating the policies depicted illustrates no step-by-step plan to achieve national security for the American people or for measuring national security strategies or which missions within the policy are more important than others.

The purpose of the research paper was to determine "How effective is the U.S. National Security Strategy Policy in protecting the American people?" President Obama repeatedly claims that the American people are securer and living more safely today than 12 years ago; other writers reviewed assert that the national security policies are too wordy but do not claim that these policies do not keep the American people safe and secure.

The present research paper, however, makes several noteworthy contributions to how the NSS Policy safeguards the American people and has identified how current governmental policies assist in the people's understanding of the role of the Executive Branch. However, the research materials covered are limited, as government policies are ever-changing and are specifically designed to meet the 
needs of the people and government within a specific timeline.

This research question has thrown up any further questions about national security and foreign policies needing investigation and in-depth review. Further work to be done to establish whether U.S. security and foreign policies are individually safeguarding the American people, its allies, its partners, and its interests. It would be interesting to compare future Presidents' national security policies to Bush and Obama's when addressing the ever-changing world in which we live. Future research should, therefore, concentrate on the step-by-step actions needed by a national policy to safeguard the American people, its allies, its partners, and its interests.

There are several significant policy changes as discussed above to be made. Taken together, these security and foreign policies support the null hypothesis. More research is needed to understand better when the implementation of security and foreign policies ends, and step-by-step actions begin.

\section{ACKNOWLEDGMENT}

I am using this opportunity to express my gratitude to my family and friends who supported me throughout the course of this research project. I am thankful for their aspiring guidance, invaluably constructive criticism and friendly advice during the project work. I am sincerely grateful to them for sharing their truthful and illuminating views on a number of issues related to the project.

\section{REFERENCES}

[1] Annual National Security Strategy Report, 50 U.S.C. § 404a (1986).

[2] Blanchard, Olivier. The Crisis: Basic Mechanisms, and Appropriate Policies. International Monetary

Fund. http://www.imf.org/external/pubs/ft/wp/2009/wp0980.pdf (acce ssed June 6, 2013)

[3] Bush, George W. 2002. "The National Security Strategy of the United States of America." https://www.state.gov (accessed June 6, 2013).

[4] 2010. "Quotes.” U.S. Global Leadership Coalition. http://www.usglc.org/budget-center/on-the-record/ (accessed June 6, 2013).

[5] Creswell, John W. 2009. Research Design: Qualitative, Quantitative, and Mixed Methods Approaches. 3rd ed. Thousand Oaks, CA: Sage.

[6] Cristescu, Claudia. 2010. "The Politicization of Intelligence: The Bonapartist intelligence Model." StudiaUniversitatis Babes-Bolyai. StudiaEuropaea 55, no. 2: 159-76.

[7] Desch, Michael C. 2010. "The More Things Change, the More They Stay the Same: The Liberal Tradition and Obama's Counterterrorism Policy." PS, Political Science \& Politics 43, no. 3: 425-29.

[8] Defense Acquisition University. "National Security Strategy (NSS).”Acquipedia.https://dap.dau.mil (accessed June 6, 2013).

[9] "DHS Recommends Use of Advanced Imaging Technology to Combat Terrorism." 2010. Foreign Policy Bulletin 20, no. 2: 32-46.

[10] Doyle, Richard B. 2007. "The U.S. National Security Strategy: Policy, Process, Problems."Public Administration Review 67, no. 4: 624-29.

[11] Fisher, Louis. The Executive Accountability Act of 2009. Library of Congress.http://loc.gov/law/help/usconlaw/pdf/H.R.\%20743.testimon y.2009.pdf (accessed June 6, 2013).

[12] Gates, Robert M. 2008. "National Defense Strategy." American Public University.https://www.amu.edu (accessed June 6, 2013).

[13] Lobel, Jules, and F. Turner Robert. 2012. "Covert War and the Constitution/Covert War and the Constitution: A Response." Journal of National Security Law \& Policy 5, no. 2: 393-407, 409-28.

[14] Manwaring, Max. 2012. "Venezuela as an Exporter of 4th Generation Warfare Instability." U.S. Army War College. http://www.strategicstudiesinstitute.army.mil/national-security-strateg y-policy/national-security-strategy (accessed June 6, 2013).

[15] Obama, Barack. n.d. "Foreign Policy." https://www.state.gov (accessed June 6, 2013).

[16] 2010. "National Security Strategy." American Public University. http://www.amu.edu (accessed June 6, 2013).
[17] 2011. "National Strategy for Counterterrorism." American Public University.https://www.amu.edu (accessed June 6, 2013).

[18] 2013. "Remarks by the President in the State of the Union Address." The White House.

http://www.whitehouse.gov/the-press-office/2013/02/12/remarks-pres ident-state-union-address (accessed June 6, 2013).

[19] 2012. "Sustaining U.S. Global Leadership: Priorities for 21st Century Defense." American Public University.https://www.amu.edu (accessed June 6, 2013).

[20] Rohde, David. 2012. “The Obama Doctrine." Foreign Policy no. 192: 65-69.

[21] Shane, Peter M. 2012. "Executive Branch Self-Policing in Times of Crisis: The Challenges for Conscientious Legal Analysis." Journal of National Security Law \& Policy 5, no. 2: 507-20.

[22] Snider, Don. 1995. "The National Security Strategy: Documenting Strategic Vision Second Edition.” Strategic Studies Institute. http://www.strategicstudiesinstitute.army.mil (accessed June 6, 2013).

[23] Whittaker, Alan G., Shannon A. Brown, Rederick C. Smith, and Elizabeth McKune. The National Security Policy Process: The National Security Council and Interagency System. National Defense University. http://www.ndu.edu/es/outreach/publications/nspp/docs/ic af-nsc-policy-process-report-08-2011.pdf (accessed June 6, 2013).

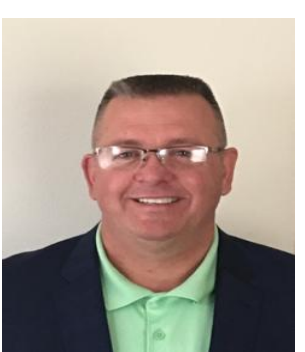

Dr. Phillip D. Clingan, Criminal Justice \& Social Sciences, Pierce College/ Lakewood WA., United States,

Dr. Clingan after serving 21 years in the United States Army undertook his Psy.D in the Department of Psychology, specializing in criminology in the School of Organizational Leadership at the University of the Rockies, Denver, Colorado. He is a faculty member teaching in the Departments of Psychology and Criminal Justice in San Antonio, Texas for Pierce College and serves as a content expert on dissertation committees for Grand Canyon University School of Doctoral Studies regarding quantitative studies for doctoral candidates. Dr. Clingan specializes in preeminent psychology as applied within the field of criminology. His psychology work is based upon field experience in criminal trials since 2013 and heavily influenced by the theoretical frameworks of Dr. Paul Ekman and measuring nonverbal communication. Loves writing and riding his Indian Motorcycle. 